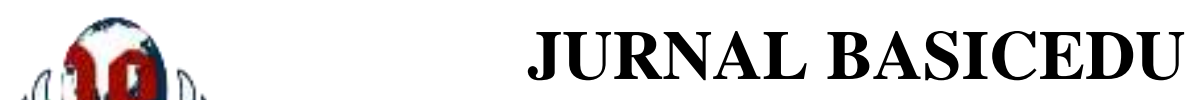

Volume 5 Nomor 6 Tahun 2021 Halaman 5313 - 5327

Research \& Learning in Elementary Education

https://jbasic.org/index.php/basicedu

PAHLATAN

\title{
Pengembangan Multimedia Pembelajaran Interaktif Berbasis Video untuk Meningkatkan Minat Belajar Siswa Sekolah Dasar
}

\author{
Sri Wulan Anggraeni ${ }^{1 \bowtie}$, Yayan Alpian², Depi Prihamdani ${ }^{3}$, Euis Winarsih ${ }^{4}$ \\ Universitas Buana Perjuangan Karawang, Indonesia ${ }^{1,2,3,4}$ \\ E-mail: wulan.anggraeni@ubpkarawang.ac.id ${ }^{1}$, yayan.alpian@ubpkarawang.ac.id ${ }^{2}$, \\ depi.prihamdani@ubpkarawang.ac.id ${ }^{3}, \underline{\text { sd17.euiswinarsih@mhs.ubpkarawang.ac.id }}^{4}$
}

\begin{abstract}
Abstrak
Antusiasme dan keaktifan siswa dalam proses pembelajaran dipengaruhi oleh minat belajar siswa. Namun kenyataan di lapangan, minat belajar siswa masih sangatlah rendah. Adapun tujuan dari penelitian ini adalah untuk mengembangkan multimedia pembelajaran interaktif berbasis video dalam menarik minat belajar siswa Sekolah Dasar. Metode penelitian yang digunakan adalah Research And Development (R\&D) dengan tujuan membuat multimedia interaktif berbasis video untuk siswa sekolah dasar dan menentukan kualitas multimedia interaktif berdasarkan penilaian ahli media, ahli materi, dan penilaian teknis. Berdasarkan hasil temuan, ahli media memiliki nilai kelayakan rata-rata 82,9\% dalam kategori baik, sedangkan ahli materi memiliki nilai kelayakan rata-rata 89,5\% dalam kategori sangat baik. Uji coba kelompok kecil memiliki skor rata-rata $82 \%$ dalam kategori baik, dan uji coba lapangan memiliki skor rata-rata 80\% dalam kategori baik, hasil penilaian guru memperoleh nilai rata-rata sebesar $92,6 \%$ pada kategori sangat baik. Adapun perolehan nilai angket minat belajar siswa dengan uji-gain di mana pada aspek perasaan senang diperoleh $\mathrm{N}$-gain sebesar 0,61 dan aspek perhatian siswa diperoleh n-gain sebesar 0,69. Sedangkan diperoleh N-gain keseluruhan aspek minat belajar siswa diperoleh 0,64 dengan peningkatan minat belajar siswa termasuk pada kategori sedang. Dengan demikian, Alhasil, pembuatan multimedia interaktif berbasis video dapat meningkatkan minat belajar siswa.
\end{abstract}

Kata Kunci: Multimedia Interaktif, Minat Belajar Siswa.

\begin{abstract}
The enthusiasm and activeness of students in the learning process is influenced by students' interest in learning. However, the reality in the field, students' interest in learning during learning activities is very low. The purpose of this research is to develop video-based interactive learning multimedia in attracting elementary school students' interest in learning. This research method is Research And Development $(R \& D)$ with the aim of making video-based interactive multimedia for elementary school students and determining the quality of interactive multimedia based on the assessment of media experts, material experts, and technical assessments. Based on the findings, media experts have an average feasibility score of $82.9 \%$ in the good category, while material experts have an average feasibility score of $89.5 \%$ in the very good category. The small group trial had an average score of $82 \%$ in the good category, and the field trial had an average score of $80 \%$ in the good category, the teacher's assessment results obtained an average score of $92.6 \%$ in the very good category. The acquisition value of the student learning interest questionnaire with a gain test in which the aspect of feeling happy obtained an N-gain of 0.61 and the attention aspect of students obtained an n-gain of 0.69 . Meanwhile, the N-gain of the overall aspects of student interest in learning was obtained 0.64 with an increase in student interest in learning, including in the medium category. Thus, as a result, making video-based interactive multimedia can increase students' interest in learning.
\end{abstract}

Keywords: Interactive multimedia, Students' interest in learning.

Copyright (c) 2021 Sri Wulan Anggraeni, Yayan Alpian, Depi Prihamdani, Euis Winarsih

$\square$ Corresponding author :

Email : wulan.anggraeni@ubpkarawang.ac.id

DOI : https://doi.org/10.31004/basicedu.v5i6.1636

ISSN 2580-3735 (Media Cetak)

ISSN 2580-1147 (Media Online)

Jurnal Basicedu Vol 5 No 6 Tahun 2021

p-ISSN 2580-3735 e-ISSN 2580-1147 
5314 Pengembangan Multimedia Pembelajaran Interaktif Berbasis Video untuk Meningkatkan Minat Belajar Siswa Sekolah Dasar - Sri Wulan Anggraeni, Yayan Alpian, Depi Prihamdani, Euis Winarsih DOI: https://doi.org/10.31004/basicedu.v5i6.1636

\section{PENDAHULUAN}

Belajar sangat penting dalam kehidupan kita karena memungkinkan kita untuk memperoleh pendidikan yang lebih tinggi. Setiap orang terus maju dalam kehidupan dan mencapai kesuksesan sebagai hasil dari belajar mereka. Hampir setiap orang sukses pernah gagal. Namun, mereka tidak menyerah, dan mencoba lagi dan lagi. Hanya sebagian kecil orang yang mencapai kesuksesan dengan cepat. Belajar dari pengalaman dan memperbaiki kekurangan yang ada adalah salah satu cara untuk mencapai dan mencicipi kesuksesan.

Belajar pada setiap individu terjadi disaat individu itu sendiri dilahirkan sampai pada kematian, karena proses belajar berlangsung sepanjang hayat. Orang belajar sebagai hasil dari interaksi mereka dengan lingkungannya. Akibatnya, pembelajaran dapat terjadi kapan saja dan di mana saja. Perubahan perilaku seseorang merupakan salah satu indikator yang menandakan orang itu telah belajar, yang mungkin menyebabkan perubahan tingkat pengetahuan, kemampuan, atau sikapnya (Arsyad, 2016).

Setiap individu tumbuh dan berkembang tentunya melalui proses belajar, di mana belajar mampu merubah serta membentuk pola atau tingkah laku individu itu sendiri. Menurut Trianto mengungkapkan bahwa dalam proses belajar, pengalaman merupakan jenis interaksi antara individu dengan lingkungannya (Putrayasa, Syahruddin, \& Margunayasa, 2014; Trianto, 2009). Lebih lanjut Fauziah menyatakan belajar bisa dipengaruhi oleh berbagai faktor, termasuk faktor internal yang mempengaruhi individu seperti kecerdasan, minat, bakat dan kemampuan, serta faktor eksternal yaitu faktor yang berada di luar individu misalnya lingkungan sekolah, keluarga dan masyarakat. Faktor dalam diri individu seperti minat belajar sangat berpengaruh dalam mendorong terjadinya kegiatan belajar, karena belajar didasarkan pada minat individu itu sendiri (Fauziah, Rosnaningsih, \& Azhar, 2017).

Minat merupakan kecenderungan hati individu pada suatu hal atau kegiatan yang dianggapnya menarik. Minat merupakan langkah awal dalam proses belajar bagi siswa untuk dapat mencapai tujuan yang diinginkan. Hal ini menunjukkan bahwa siswa dengan minat belajar yang tinggi akan dapat memenuhi cita-citanya, sedangkan siswa dengan minat belajar yang rendah tidak akan mampu melakukannya (Fauziah et al., 2017; Komariyah, Afifah, \& Resbiantoro, 2018).

Guru yang profesional harus mampu menyelidiki apa saja yang dapat menarik perhatian siswanya. Namun, setiap keterampilan dasar mungkin memiliki tingkat kesulitan yang berbeda. Kemampuan siswa juga berbeda. Jadi, meskipun membangkitkan minat belajar itu sulit, seorang guru yang berkompeten harus mampu melakukannya agar proses pembelajaran dapat berjalan dengan lancar dan aktif. Karena siswa termotivasi dan semangat belajar bila ada motivasi belajar yang kuat terutama dari guru. Siswa juga mampu menerima, memahami, dan menguasai materi pelajaran yang dipelajarinya. Siswa yang dapat menyelesaikan tugas akan memiliki tingkat pencapaian belajar yang tinggi (Friantini \& Winata, 2019).

Kenyataan di lapangan, minat belajar siswa selama kegiatan pembelajaran sangat kurang. Seperti yang ditemukan oleh pada siswa kelas V SDN Lemahmukti II, siswa kurang semangat dan tertarik dalam kegiatan belajar sehingga siswa tidak memperhatikan guru ketika mengajar, dan siswa tidak mengerti pelajaran, yang berdampak pada hasil belajar yang rendah. Keterlibatan siswa dalam kegiatan pembelajaran sangat minim. Ketika guru mengajukan pertanyaan, hanya beberapa siswa yang menjawab. Begitu pula ketika guru memberikan kesempatan kepada siswa untuk bertanya, tidak ada satupun siswa yang mengajukan pertanyaan yang berkaitan dengan tema pelajaran yang diajarkan guru.

Rendahnya minat belajar siswa bukan tidak beralasan, ini dapat disebabkan dari faktor eksternal yaitu guru tidak memanfaatkan penggunaan media pembelajaran yang dapat mengguggah siswa dan menarik minat belajar siswa, hal ini dikarenakan kurangnya pengetahuan dan keterampilan yang dimiliki guru dalam penggunaan media pembelajaran sehingga guru hanya memberikan tugas-tugas dari lembar kerja siswa saja. Tentu saja hal ini dapat membuat minat belajar siswa rendah. Sebagaimana yang diungkapkan Melaputri dkk (Awalia, Ika Ari Pratiwi, \& Kironoratri, 2021) berpendapat bahwa minat belajar dapat ditimbukan dengan 
5315 Pengembangan Multimedia Pembelajaran Interaktif Berbasis Video untuk Meningkatkan Minat Belajar Siswa Sekolah Dasar - Sri Wulan Anggraeni, Yayan Alpian, Depi Prihamdani, Euis Winarsih DOI: https://doi.org/10.31004/basicedu.v5i6.1636

cara menerapkan model pembelajaran yang menyenangkan dan menuntut keaktifan siswa, maka secara perlahan akan timbul minat belajar pada diri siswa dan pada akhirnya bermuara pada hasil belajar yang optimal pula.

Berdasarkan kenyataan di atas, sistem pembelajaran yang terjadi selama ini masih bersifat konvensional. Guru masih menggunakan buku teks dalam menjelaskan materi, pengerjaan tugas masih menggunakan LKS, dan guru minim menggunakan media pembelajaran. Sodikin mengungkapkan bahwa sistem pembelajaran konvensional (faculty teaching) kental dengan suasana pembelajaran yang dianggap kurang sesuai dengan dinamika perkembangan ilmu pengetahuan dan teknologi yang semakin pesat. Guru harus secara intensif menyesuaikan materi pelajaran dengan keamjuan teknologi terkini, sistem pembelajaran tradisional kurang fleksibel dalam mengakomodasi perkembangan materi kompetensi (Baharun, 2016; Darmadi, 2017). Akibat sistem pembelajaran konvensional adalah adalah pembelajaran tidak kondusif yaitu Pada saat pembelajaran berlangsung, siswa lelah atau mengobrol di kelas, siswa kurang konsentrasi terhadap penjelasan guru, rasa ingin tahu siswa kurang, siswa tidak berani berpendapat atau pasif di kelas, dan banyak siswa yang belum memenuhi target Kriteria Ketuntasan Minimum (KKM). Maka dari itu, pembelajaran harus dirancang sedemikian rupa, tentunya dalam pelaksanaan proses pembelajaran, guru perlu menyiapkan berbagai media pembelajaran sebagai perantara kegiatan belajar.

Media memiliki peran penting sebagai perantara dalam penyampaian materi pembelajaran, sebagai contohnya media interaktif. Media ini merupakan komponen pembelajaran yang sangat signifikan. Penggunaan media di dalam kelas dapat memberikan dampak positif yang sangat besar bagi proses belajar siswa. Lebih lanjut, media pembelajaran merupakan fondasi penting yang berfungsi sebagai pelengkap dan bagian vital dari keberhasilan proses pembelajaran (Wulandari, Widyaningrum, \& Arini, 2021). Untuk itu, perlu dikembangkannya multimedia pembelajaran guna menunjang kegiatan pembelajaran berlangsung.

Multimedia interaktif ialah media yang dapat dimanfaatkan untuk memperjelas proses pembelajaran jika didukung oleh media pembelajaran yang dapat menarik minat dan atensi siswa sehingga dapat menyediakan lingkungan belajar yang adaptif serta variatif, siswa juga bisa mengendalikan dan menentukan sendiri urutan materi pembelajaran yang sesuai dengan keinginan. Dengan menggabungkan berbagai komponen (teks, grafik, audio, video/animasi) dan menggunakan komputer/laptop untuk mengilustrasikan suatu konsep melalui animasi, suara, dan peragaan yang menarik, multimedia interaktif dalam pembelajaran dapat menghasilkan pembelajaran yang efektif yang memungkinkan siswa berkembang sesuai dengan kemampuannya masing-masing (Bintas \& Gelibolu, 2010; Kustandi \& Sutjipto, 2011).

Menurut Hamalik (Kustandi \& Darmawan, 2020) menyatakan bahwa penggunaan media dalam pembelajaran merupakan proses belajar dan mengajar yang dapat memicu keinginan dan minat siswa, memberikan motivasi dan merangsang proses belajar, serta memberikan dampak psikologis bagi siswa. Hal ini sejalan dengan Kustandi, Sujipto (2011) mengungkapkan bahwa media pembelajaran adalah alat untuk meningkatkan kegiatan belajar mengajar dengan memperjelas makna pesan yang disampaikan, sehingga memungkinkan tercapainya tujuan pembelajaran dengan lebih baik dan tepat (Kustandi \& Sutjipto, 2011).

Berdasarkan identifkasi masalah di atas dapat dilakukan pembatasan masalah pada permasalahan tersebut yaitu minat belajar siswa selama kegiatan pembelajaran sangat rendah, guru tidak memanfaatkan teknologi komunikasi sebaik mungkin misalnya dengan pemanfaatan multimedia pembelajaran interaktif yang tersedia. Maka dari itu, penelitian ini penting dilakukan untuk meningkatkan minat belajar siswa melalui multimedia interaktif berbasis video. Tentunya dalam pengembangan multimedia pembelajaran interaktif harus dikembangkan berdasarkan tujuan, kompetensi dan indikator yang ingin dicapai, serta efektif dan efesiensi dalam penggunaannya.

Penggunaan multimedia interaktif dapat mengatasi permasalahan dalam pembelajaran. Hasil penelitian terdahulu Rahaju Muljo Wulandari, dkk mengungkapkan bahwa hasil dari model pembelajaran melalui media pembelajaran melalui video interaktif mampu memotivasi siswa sehingga dapat prestasi belajar meningkat. 
Siswa memberikan respon positif terhadap implementasi model pembelajaran menggunakan video interaktif (Wulandari et al., 2021). Penggunaan video interaktif yang digunakan Rahaju Muljo Wulandari, dkk berisi tentang Sistem Muskuloskeletal, sedangkan video interaktif pada penelitian ini tentang siklus air. Adapun dasar dari pengembangan video interaktif ini berasal dari buku tema kelas V SD semester 2, Tema lingkungan sahabat kita, sub tema perubahan lingkungan. Pada buku tema tersebut, materi hanya dijelaskan dalam bentuk teks, dan siswa perlu berpikir lebih dalam memahami materi tersebut. Maka dari itu, perlu adanya pengembangan bahan ajar berbasis pada video interaktif.

Pada penelitian ini, media yang digunakan adalah multimedia interaktif berbasis video dengan penyampaian melalui animasi yang dapat bergerak, terdapat suara dan gambar yang menarik sehingga dapat menarik perhatian siswa. Siswa juga dapat belajar melalui media pembelajaran yang disediakan oleh guru kapan saja dan dimana saja, di mana media ini dimaksudkan agar siswa tertarik dalam melaksanakan kegiatan belajar selama proses pembelajaran. Apalagi pengemasan program penggunaan dan metode medianya menggunakan karakter kartun yang sangat digemari oleh anak-anak (Nusir, Alsmadi, Al-Kabi, \& Sharadgah, 2013). Oleh karena itu, multimedia berbasis video interaktif pada penelitian ini cara penyajiannya dengan menggunakan animasi sehingga dapat menarik perhatian siswa dalam melaksanakan kegiatan belajar. Menurut Kumala (Niswa, 2012) menyatakan kelebihan video interaktif diantaranya praktis digunakan, menarik perhatian siswa, tidak monoton, serta menyenangkan.

Sejalan dengan permasalahan di atas, untuk meningkatkan minat belajar siswa diperlukan inovasi dalam pembelajaran, salah satunya adalah pengembangan multimedia pembelajaran interaktif berbasis video dengan tujuan untuk mengembangkan multimedia pembelajaran interaktif berbasis video dalam menarik minat belajar siswa kelas V Sekolah Dasar. Diharapkan dengan menggunakan multimedia pembelajaran ini, minat belajar siswa akan meningkat selama proses pembelajaran berlangsung dan dapat terciptanya kondisi belajar yang kondusif untuk mencapai tujuan pembelajaran.

\section{METODE}

Penelitian ini menggunakan pendekatan penelitian R\&D (Research and Development), yang sering disebut dengan penelitian pengembangan. Menurut Sugiyono (Saifudin, Susilaningsih, \& Wedi, 2020) menyatakan bahwa metode penelitian dan pengembangan adalah teknik untuk menciptakan produk yang layak dan mengevaluasi keefektifannya.

Produk yang dihasilkan dari riset ini ialah pengembangan multimedia pembelajaran interaktif yang akan disajikan dalam bentuk video. Sasaran produk pada riset ini ialah untuk siswa kelas V SDN Lemahmukti II Kabupaten Karawang Jawa- Barat.

Adapun langkah- langkah dalam riset serta pengembangan ada 10 langkah, antara lain potensi serta masalah, pengumpulan informasi, desain produk, validasi desain, perbaikan desain, uji coba produk, perbaikan produk, uji coba pemakaian, perbaikan produk, serta produksi masal.

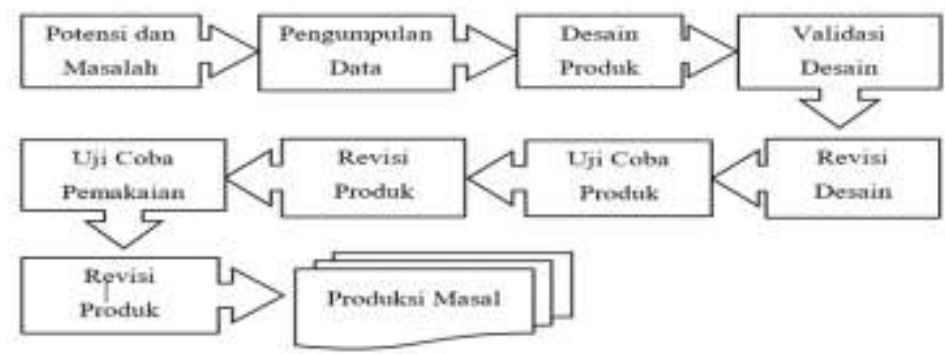

Gambar 1. Prosedur pengembangan produk (Sugiyono, 2008) 
5317 Pengembangan Multimedia Pembelajaran Interaktif Berbasis Video untuk Meningkatkan Minat Belajar Siswa Sekolah Dasar - Sri Wulan Anggraeni, Yayan Alpian, Depi Prihamdani, Euis Winarsih DOI: https://doi.org/10.31004/basicedu.v5i6.1636

Bersumber pada langkah- langkah penelitian dan pengembangan tersebut, maka peneliti membatasi penelitian dan pengembangan hanya pada tahap ke delapan saja berdasarkan kebutuhan peneliti. Adapun langkah-langkah dari penelitian dan pengembangan ini disesuaikan dari penelitian dan pengembangan Sugiyono, sebagai berikut:

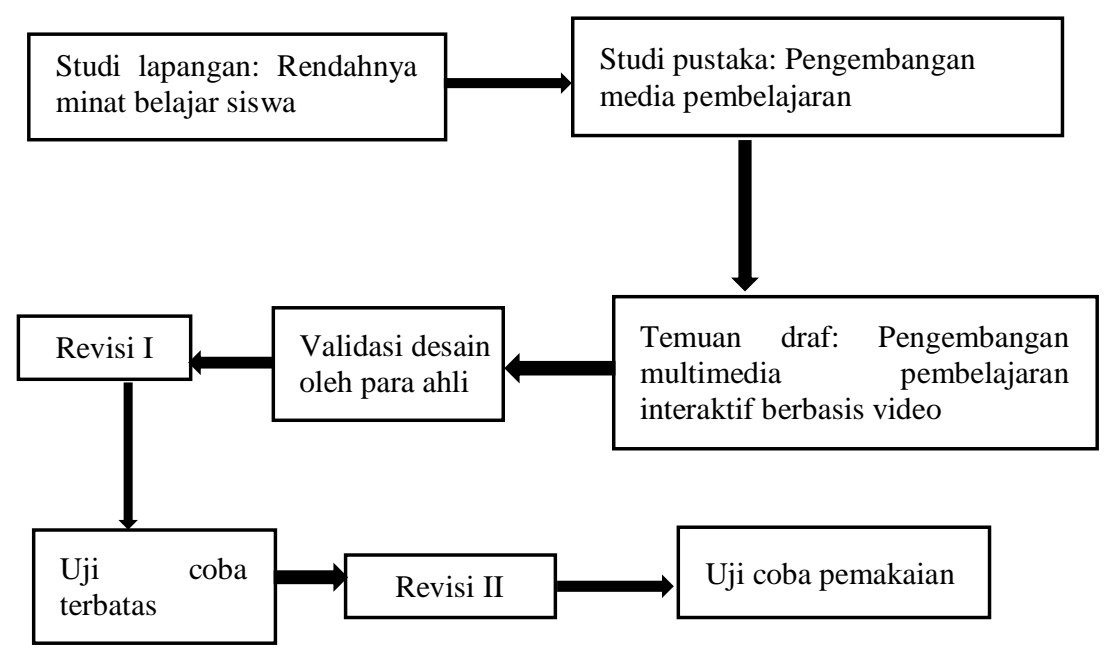

Gambar 2. Langkah-langkah penelitian dan pengembangan yang dimodifikasi dari penelitian Sugiyono 2009

Adapun cara mengumpulkan data dalam penelitian ini yaitu dengan menggunakan teknik observasi, wawancara dan dokumentasi. Dan data mengenai validasi produk menggunakan instrumen angket dengan format ceklist dengan beberapa butir pernyataan, angket diberikan kepada ahli media, dan ahli materi. Sedangkan data mengenai peningkatan minat belajar siswa melalui multimedia pembelajaran interaktif berbasis video diambil dengan menggunakan instumen angket dengan format ceklist dengan beberapa pernyataan berdasarkan indikator minat belajar siswa melalui media pembelajaran. Selain itu, instrumen mengenai tanggapan guru dan siswa terhadap produk yang dikembangkan menggunakan teknik angket.

Teknik analisis data mengenai hasil validasi oleh ahli media, ahli materi dan uji coba kelompok kecil, kelompok besar, serta tanggapan guru untuk menghitung hasil angket di analisis menggunakan rumus, sebagai berikut.

$$
\begin{aligned}
& N=\frac{k}{N K} \times 100 \% \\
& \text { Keterangan: } \\
& N \quad: \text { Persentase skor } \\
& K \quad: \text { Skor perolehan } \\
& N K \quad: \text { Skor maksimal }
\end{aligned}
$$

Berdasarkan perhitungan tersebut maka mendapatkan kriteria kualitatif, sebagai berikut.

Tabel 1. Range persentase kualitatif

\begin{tabular}{ll}
\hline Interval & Kriteria \\
\hline $81,25 \%>$ Skor $\leq 100 \%$ & Sangat Baik \\
\hline $62,50 \%>$ Skor $\leq 81,25 \%$ & Baik \\
\hline $43,75 \%$ Skor $\leq 62,50 \%$ & Cukup Baik \\
\hline $25 \% \geq$ Skor $\leq 43,75 \%$ & Kurang Baik \\
\hline
\end{tabular}


5318 Pengembangan Multimedia Pembelajaran Interaktif Berbasis Video untuk Meningkatkan Minat Belajar Siswa Sekolah Dasar - Sri Wulan Anggraeni, Yayan Alpian, Depi Prihamdani, Euis Winarsih DOI: https://doi.org/10.31004/basicedu.v5i6.1636

Untuk mengetahui peningkatan pada minat belajar siswa sebelum dan sesudah diberikan perlakuan, digunakan uji N-Gain, adapun rumus uji N-Gain, sebagai berikut.

$$
N \text {-gain }(g)=\frac{\text { Skor postest }- \text { Skor pretest }}{\text { Skor maksimal }- \text { skor pretest }}
$$

Keterangan:

$N$-gain

Skor postest

Skor pretest

Skor maksimal
: Besarnya faktor gain

: Nilai hasil tes akhir

: Nilai hasil tes awal

: Nilai maksimal tes

Tabel 2. Persentase kriteria faktor gain

\begin{tabular}{ll}
\hline Interval & Kriteria \\
\hline $\mathrm{g}>0,7$ & Tinggi \\
\hline $0,3 \leq \mathrm{g} \leq 0,7$ & Sedang \\
\hline $\mathrm{G}<0,3$ & Rendah \\
\hline
\end{tabular}

\section{HASIL DAN PEMBAHASAN}

Hasil penelitian ini akan difokuskan pada pengembangan multimedia interaktif berbasis video untuk meningkatkan minat belajar siswa. Hasil dari penelitian ini meliputi: 1) hasil pengembangan produk; 2) kelayakan produk; 3) Efektifitas Produk; 4) Hasil Minat Belajar Siswa.

\section{Hasil Pengembangan Produk}

Pengembangan produk dalam penelitian ini dimulai dari analisis kebutuhan yang dilakukan untuk memperkirakan apa saja yang menjadi hambatan dan kebutuhan siswa selama proses kegiatan belajar berlangsung. Berdasakan data hasil wawancara dengan siswa, dikatakan bahwa siswa kurang bersemangat selama kegiatan pembelajaran, proses pembelajaran masih menggunakan media LKS saja dimana guru tidak memanfaatkan media pembelajaran untuk menarik perhatian siswa dalam belajar, sehingga minat belajar siswa kurang maksimal. Oleh karena itu, diperlukan pengembangan media video sebagai penunjang kegiatan belajar dan mengajar agar ketertarikan siswa untuk belajar lebih maksimal.

Produk multimedia interaktif yang dikembangkan berupa video pembelajaran mengenai materi "siklus air" untuk kelas V sekolah dasar. Proses produksi media yang dikembangkan menggunakan aplikasi atau sofware Adobe Plash CS5 dan menggunakan aplikasi Kinemaste sebagai software pendukung. Video disajikan dalam bentuk DVD dengan durasi 7 menit. Isi video pembelajaran interaktif meliputi tampilan utama yang terdiri dari menu kompetensi inti, kompetensi dasar, indikator, tujuan pembelajaran yang harus dicapai, materi pelajaran dengan tema "siklus air", evaluasi sebagai penugasan akhir materi, dan menu keluar.

Adapun langkah-langkah produksi media pembelajaran yang dikembangkan, yaitu:

a. Menyiapkan perangakat yang dibutuhkan dalam merancang dan membuat media pembelajaran seperti software Adobe Flash CS5 dan aplikasi Kinemaster untuk mengisi animasi, audio dan sebagai finising mengolah media video.

b. Merancang materi yang akan dituangkan pada media, materi dibagi menjadi beberapa topik bahasan per layer pada video. Kemudian mencari beberapa gambar, animasi yang sesuai dengan isi dari materi pada media, kemudian gambar dan animasi yang dicari secara online disatukan dengan diedit terlebih dahulu sebelum dituangkan pada media. 
5319 Pengembangan Multimedia Pembelajaran Interaktif Berbasis Video untuk Meningkatkan Minat Belajar Siswa Sekolah Dasar - Sri Wulan Anggraeni, Yayan Alpian, Depi Prihamdani, Euis Winarsih DOI: https://doi.org/10.31004/basicedu.v5i6.1636

c. Membuat desain awal media dengan menggunakan software Adobe Plash CS5, desain awal ini membuat layer tampilan layar media yang dilengkapi dengan tombol-tombol aktif yang ketika di klik akan menampilkan layar yang dituju.

d. Melakukan editor pada media seperti menambahkan gambar, animasi, dan teks tambahan dengan menggunakan aplikasi Kinemaster.

e. Langkah terakhir melakukan dubbing pada aplikasi Kinemaster berdasarkan materi yang terdapat pada media, serta menuangkan backsound kemudian finishing dengan di olah menjadi media video.

Adapun visualisasi dari hasil revisi pembuatan media pembelajaran berbasis video interaktif yang dilakukan peneliti, dengan menggunakan software Adobe Plash CS5 dan aplikasi Kinemaster, yaitu:

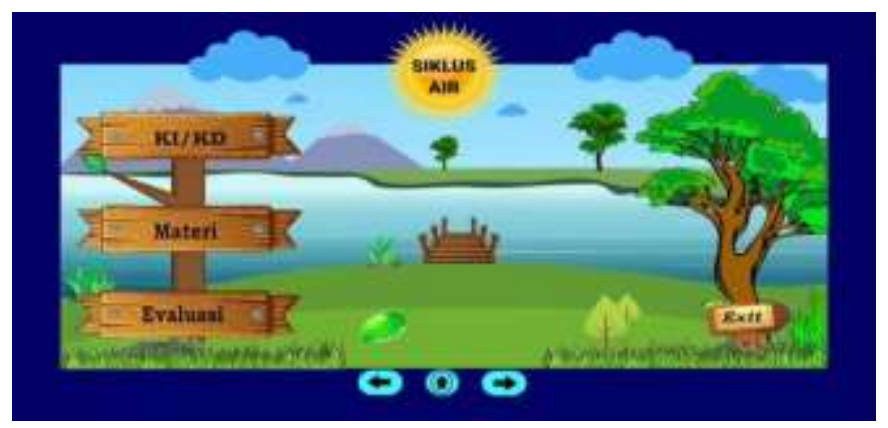

Gambar 3. Pembuka

Bagian pembuka pada media pembelajaran berbasis video ini dibuat menggunakan software Adobe Plash CS5 dengan dibantu aplikasi Kinemaster untuk menambahkan efek backsound dan dubbing isi, serta penyempurnaan gambar dan animasi. Pembuka ini di awali dengan suara dubbing pengembang dengan menanyakan kabar, dan menjelaskan materi yang akan dipelajari dilengkapi dengan animasi awan, matahari, dan kupu-kupu yang bergerak sehingga dapat menarik perhatian siswa.

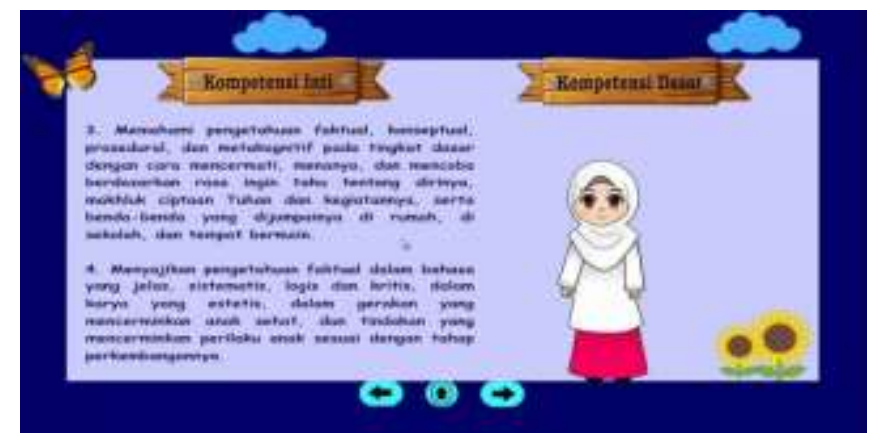

Gambar 4. Penyampaian KI,KD, Indikator dan Tujuan

Pada bagian selanjutnya muncul animasi seorang guru yang akan menjelaskan kompetensi inti, kompetensi dasar, indikator dan tujuan pembelajaran. Penjelasan tersebut muncul secara bergantian, dengan dilengkapi animasi yang dapat menarik perhatian siswa. 
5320 Pengembangan Multimedia Pembelajaran Interaktif Berbasis Video untuk Meningkatkan Minat Belajar Siswa Sekolah Dasar - Sri Wulan Anggraeni, Yayan Alpian, Depi Prihamdani, Euis Winarsih DOI: https://doi.org/10.31004/basicedu.v5i6.1636

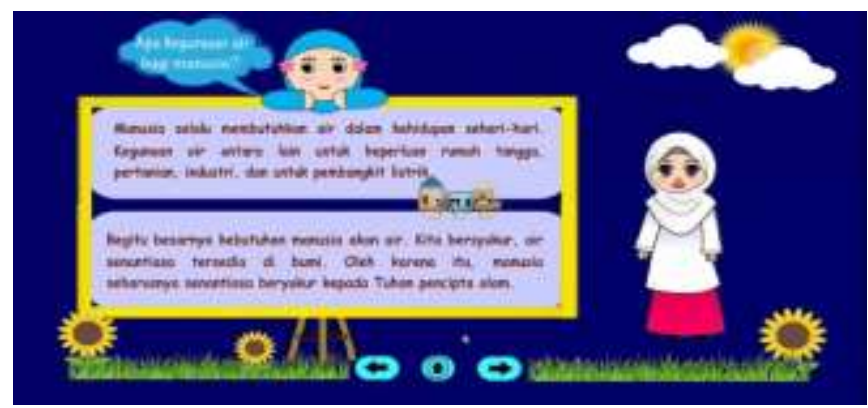

Gambar 5. Penjelasan Manfaat Air Bagi Manusia

Bagian ini diawali dengan penjelasan mengenai kegunan air bagi manusia dengan munculnya animasi seorang guru dengan menjelaskan teks narasi yang terdapat pada media.

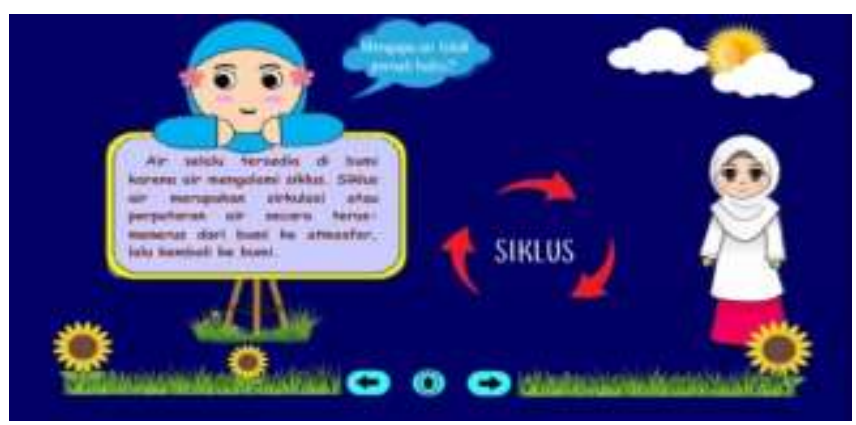

Gambar 6. Penjelasan Pengertian Siklus Air

Pada bagian ini muncul animasi seorang guru dengan di awali bertanya mengapa air tidak pernah habis, serta menjabarkan apa itu siklus air. Kemudian disusul munculnya tiga panah merah bersiklus.

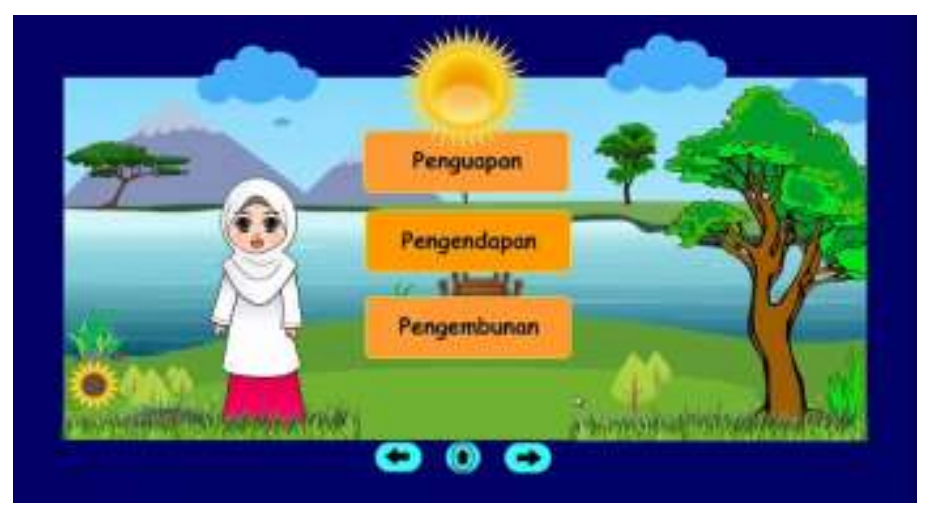

Gambar 7. Penjelasan Tahap-Tahap Siklus Air

Pada bagian ini menyebutkan tahapan-tahapan dari proses siklus air, yang diawali dengan munculnya animasi seorang guru, kemudian disusul dengan dua panah merah satu-persatu yang menunjukan proses siklus. Kemudian mengajak siswa untuk menyimak teks penjelasan dari ke tiga proses tersebut. 
5321 Pengembangan Multimedia Pembelajaran Interaktif Berbasis Video untuk Meningkatkan Minat Belajar Siswa Sekolah Dasar - Sri Wulan Anggraeni, Yayan Alpian, Depi Prihamdani, Euis Winarsih DOI: https://doi.org/10.31004/basicedu.v5i6.1636

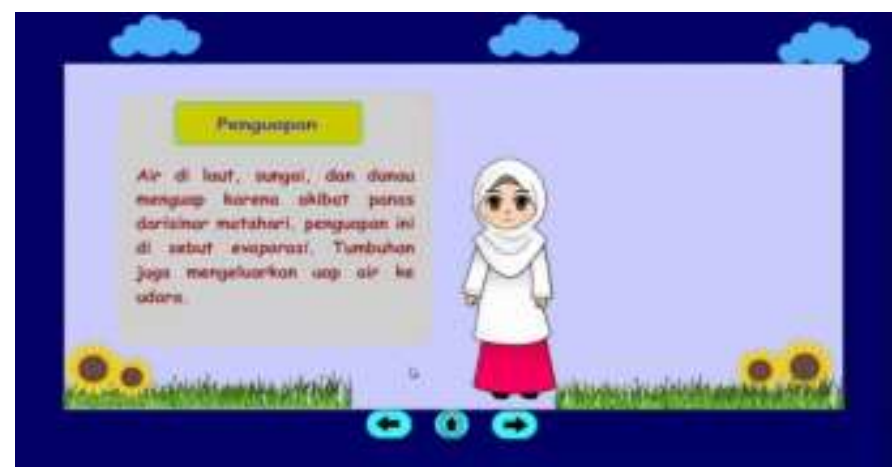

Gambar 8. Penjelasan Pengertian Penguapan, Pengendapan dan Pengembunan

Pada bagian ini diawali dengan teks penjelasan mengenai penguapan, lalu munculnya animasi seorang guru yang menjelaskan teks tersebut, kemudian disusul secara bergantian menuju teks pengendapan ke pengembunan.

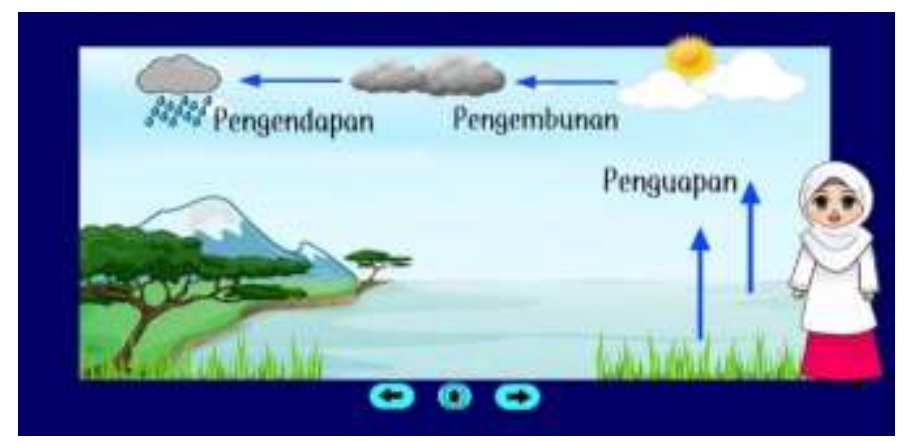

Gambar 9. Penjelasan Proses Siklus Air

Pada bagian ini diawali dengan munculnya animasi seorang guru lalu menjelaskan gambaran dari proses siklus air dengan sistematis, di awali dengan munculnya tanda panah biru ke atas, lalu awan putih dan teks penguapan, kemudian dilanjut panah biru ke samping kemudian muncul awan berwarna abu-abu dan teks pengembunan, kemudian muncul kembali panah biru ke samping disusul awan berhujan dengan teks pengendapan.

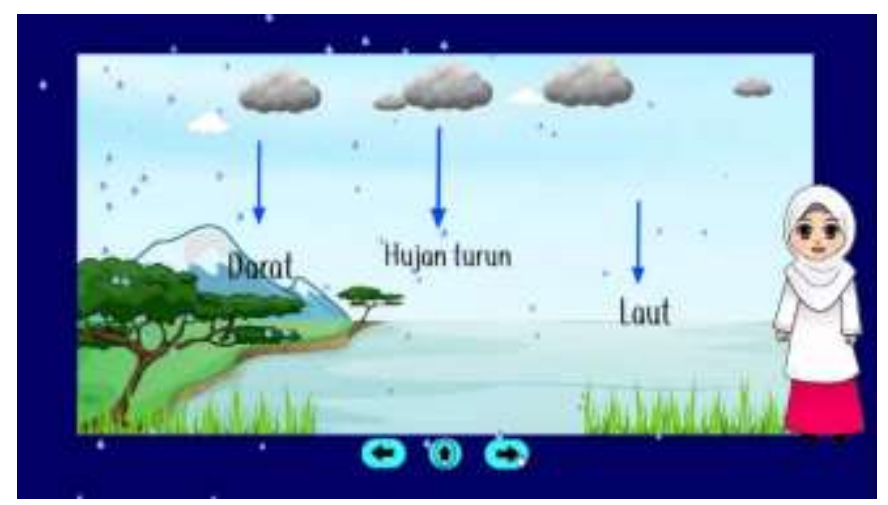

Gambar 10. Penjelasan Proses Hujan 
5322 Pengembangan Multimedia Pembelajaran Interaktif Berbasis Video untuk Meningkatkan Minat Belajar Siswa Sekolah Dasar - Sri Wulan Anggraeni, Yayan Alpian, Depi Prihamdani, Euis Winarsih DOI: https://doi.org/10.31004/basicedu.v5i6.1636

Pada bagian ini muncul animasi seorang guru, lalu menjelaskan proses terjadinya hujan setelah siklus air, yang di awali dengan munculnya gambar awan kemudian disusul tanda panah biru ke bawah lalu turun hujan, kemudian disusul dua tanda panah biru ke bawah dengan teks darat dan laut.

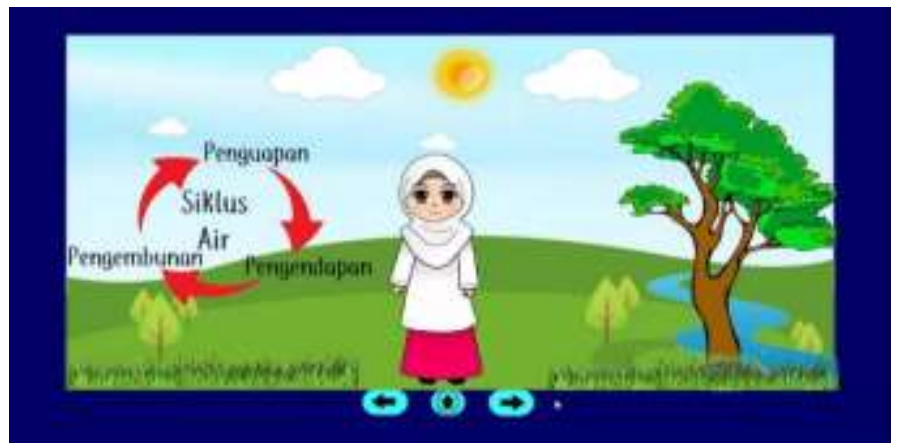

Gambar 11. Penjelasan Kesimpulan Materi

Pada bagian ini di awali dengan animasi seorang guru kemudian muncul gambar tanah dan sumur lalu menjelaskan air tanah dan air sumur yang meresap setelah turun hujan, secara bergantian dilanjut dengan teks kesimpulan berwarna biru, lalu berganti di susul munculnya tiga siklus panah merah dengan teks.

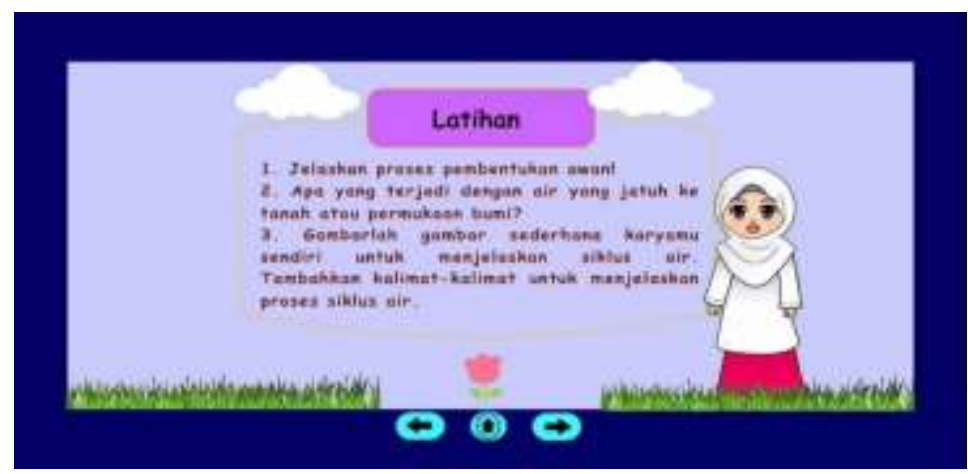

Gambar 12. Penjelasan Evaluasi Materi

Pada bagian ini muncul animasi seorang guru, dan menjelaskan latihan soal yang harus di isi oleh siswa, serta membacakan teks latihan soal kemudian kembali ke menu utama, layar pertama kemudian menutup pelajaran dengan harapan pembelajaran kali ini dapat bermanfaat bagi siswa.

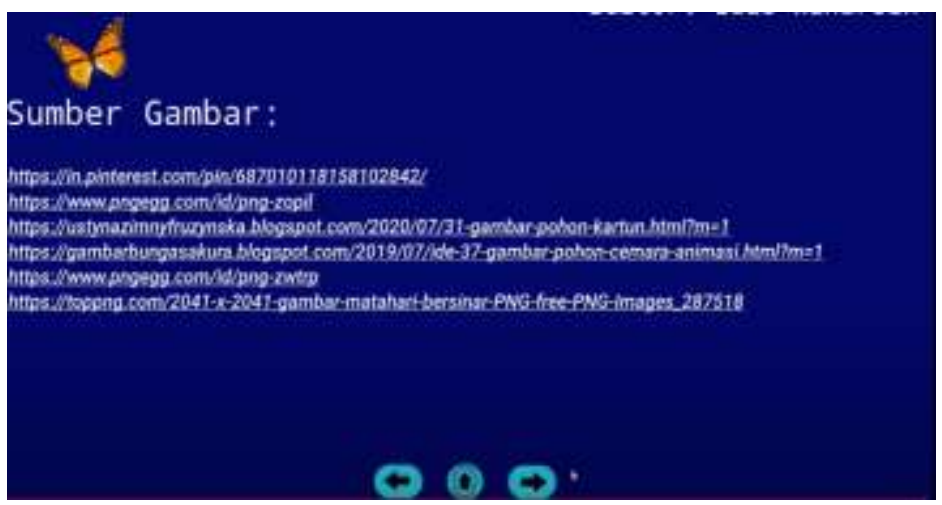

Gambar 13. Penutup (Sumber-Gambar) 
5323 Pengembangan Multimedia Pembelajaran Interaktif Berbasis Video untuk Meningkatkan Minat Belajar Siswa Sekolah Dasar - Sri Wulan Anggraeni, Yayan Alpian, Depi Prihamdani, Euis Winarsih DOI: https://doi.org/10.31004/basicedu.v5i6.1636

Bagian ini merupakan tampilan terakhir dari media pembelajaran berbasis video. Bagian ini berisi tentang sumber gambar yang digunakan.

\section{Kelayakan Produk}

Sebelum diujicobakan produk yang dihasilkan, dikembangkan berdasarkan hasil validasi para pakar atau ahli, validasi produk dilakukan pada ahli media, dan ahli materi. Penilaian pakar media pada produk yang dihasilkan dilakukan dengan cara memberikan produk multimedia pembelajaran interaktif berbasis video beserta lembar penilaian berupa angket berisi 14 pernyataan yang berkaitan dengan produk yang dikembangkan. Berikut hasil validasi ahli media.

Tabel 3. Hasil Validasi Ahli Media

\begin{tabular}{llcccc}
\hline No & $\begin{array}{c}\text { Aspek yang } \\
\text { Dinilai }\end{array}$ & Skor & $\begin{array}{c}\text { Nilai } \\
\text { Maksimal }\end{array}$ & Persentase & Ket. \\
\hline 1 & Aspek Media & 20 & 28 & $71,4 \%$ & Baik \\
\hline 2 & Mutu Teknis & 18 & 20 & $90,0 \%$ & Sangat Baik \\
\hline 3 & Ukuran Fisik Media & 7 & 8 & $87,5 \%$ & Sangat Baik \\
\hline
\end{tabular}

Berdasarkan hasil penilaian ahli media diatas, diperoleh validasi aspek media sebesar 71,4\% termasuk pada kategori baik, penilaian pada aspek mutu teknis sebesar 90,0\% dengan termasuk kategori sangat baik, serta penilaian pada aspek ukuran dan fisik media sebesar 87,5\% termasuk pada kategori sangat baik. Data tersebut menunjukan bahwa multimedia pembelajaran berbasis video interaktif untuk kelas $\mathrm{V}$ sekolah dasar termasuk pada kategori sangat baik dilihat dari penilaian aspek media, mutu teknis, dan ukuran fisik media.

Selanjutnya penilaian validasi materi dilakukan dengan cara memberikan produk multimedia pembelajaran interaktif berbasis video beserta lembar penilaian berupa angket berisi 10 pernyataan yang berkaitan dengan produk yang dikembangkan. Berikut hasil penilaian dari ahli materi.

Tabel 4. Hasil Validasi Ahli Materi

\begin{tabular}{clcccc}
\hline No & \multicolumn{1}{c}{$\begin{array}{c}\text { Aspek yang } \\
\text { Dinilai }\end{array}$} & Skor & $\begin{array}{c}\text { Nilai } \\
\text { Maksimal }\end{array}$ & Persentase & Ket. \\
\hline 1 & Cakupan Materi & 7 & 8 & $87,5 \%$ & Sangat Baik \\
\hline 2 & Akurasi Materi & 7 & 8 & $87,5 \%$ & Sangat Baik \\
\hline 3 & Kemutakhiran & 4 & 4 & $100 \%$ & Sangat Baik \\
\hline 4 & $\begin{array}{l}\text { Merangsang } \\
\text { Keinginan }\end{array}$ & 7 & 8 & $87,5 \%$ & Sangat Baik \\
\hline 5 & Penyajian Media & 10 & 12 & $83,3 \%$ & Sangat Baik \\
\hline
\end{tabular}

Berdasarkan hasil penilaian ahli materi di atas, diperoleh nilai pada cakupan materi $87,5 \%$ termasuk pada kategori sangat baik, nilai pada spek cakupan materi diperoleh sebesar 87,5\% dengan kategori sangat baik, penilaian pada aspek kemutakhiran diperoleh nilai $100 \%$ dengan kategori sangat baik, nilai pada aspek merangsang keinginan diperoleh sebesar $87,5 \%$ dengan kategori sangat baik, serta penilaian pada aspek penyajian media sebesar $83,3 \%$ dengan kategori sangat baik. Data tersebut menunjukan bahwa multimedia pembelajaran berbasis video interaktif untuk siswa kelas $\mathrm{V}$ sekolah dasar termasuk pada kategori sangat baik.

\section{Efektifitas Produk}

Efektifitas produk yang dikembangkan dilakukan dengan melalui uji coba yang dilakukan pada kelompok kecil dan kelompok besar. Uji coba kelompok kecil dilakukan pada 6 responden siswa kelas V SD Negeri Plawad VI. Masing-masing siswa diberikan angket pernyataan mengenai produk yang dikembangkan peneliti. Adapun hasil perolehan melalui uji coba kelompok kecil adalah, sebagai berikut: 
5324 Pengembangan Multimedia Pembelajaran Interaktif Berbasis Video untuk Meningkatkan Minat Belajar Siswa Sekolah Dasar - Sri Wulan Anggraeni, Yayan Alpian, Depi Prihamdani, Euis Winarsih DOI: https://doi.org/10.31004/basicedu.v5i6.1636

Tabel 5. Hasil Tanggapan Siswa Terhadap Multimedia Pembelajaran Interaktif Berbasis Video Pada Uji Coba Kelompok Kecil

\begin{tabular}{ccc}
\hline \multirow{2}{*}{ No. Responden } & Jumlah Penialian & Persentase \% \\
\hline 1 & 27 & 84,37 \\
\hline 2 & 29 & 90,62 \\
\hline 3 & 25 & 78,12 \\
\hline 4 & 24 & 75,00 \\
\hline 5 & 24 & 75,00 \\
\hline 6 & 25 & 78,12 \\
\hline Skor Maksimal & 32 & 100 \\
\hline Rata-rata & 25,66 \\
\hline Kategori & $\mathbf{8 0 , 2 1 \%}$ (Baik) \\
\hline \multicolumn{2}{c}{} \\
\hline
\end{tabular}

Berdasarkan gambar diatas diketahui bahwa pada uji coba kelompok kecil terhadap media yang dikembangkan diperoleh nilai rata-rata sebesar $80,21 \%$ dengan ketentuan media sangat baik. Hal ini dapat dinyatakan bahwa siswa tertarik belajar menggunakan produk multimedia pembelajaran interaktif berbasis video yang dikembangkan.

Pada uji coba kelompok besar dilakukan pada seluruh siswa kelas V SD Negeri Lemahmuki II sebanyak 27 siswa. Adapun hasil perolehan melalui uji coba kelompok besar adalah, sebagai berikut:

Tabel 6. Hasil Tanggapan Siswa Terhadap Multimedia Pembelajaran Interaktif Berbasis Video Pada Uji Coba Kelompok Besar

\begin{tabular}{|c|c|c|}
\hline Perolehan & Skor & Persentase $\%$ \\
\hline Nilai Tertinggi & 29 & 90,6 \\
\hline Nilai Terendah & 22 & 68,7 \\
\hline Skor Maksimal & 32 & 100 \\
\hline Rata-rata & 25,7 & 80,2 \\
\hline Kategori & \multicolumn{2}{|c|}{$80,2 \%$ (Baik) } \\
\hline
\end{tabular}

Berdasarkan tabel diatas diketahui bahwa pada uji coba kelompok besar terhadap multimedia interaktif berbasis video, diperoleh nilai rata-rata hasil angket sebesar 25,7 dengan persentase nilai sebesar 80,2\% termasuk pada kategori baik. Hal ini dapat dinyatakan bahwa siswa tertarik belajar menggunakan produk multimedia pembelajaran interaktif berbasis video yang dikembangkan peneliti.

Adapun hasil penilaian tanggapan guru mengenai produk yang dikembangkan adalah, sebagai berikut.

Tabel 7. Hasil Penilaian Tanggapan Guru

\begin{tabular}{clccccc}
\hline No & $\begin{array}{c}\text { Aspek yang } \\
\text { dinilai }\end{array}$ & $\begin{array}{c}\text { Nilai } \\
\text { Guru 1 }\end{array}$ & $\begin{array}{c}\text { Nilai } \\
\text { Guru 2 }\end{array}$ & $\begin{array}{c}\text { Nilai } \\
\text { Maksimal }\end{array}$ & Persentase & Ket. \\
\hline 1 & $\begin{array}{l}\text { Aspek } \\
\text { isi/materi }\end{array}$ & 8 & 7 & 8 & $93,7 \%$ & $\begin{array}{c}\text { Sangat } \\
\text { baik }\end{array}$ \\
\hline 2 & Aspek media & 22 & 22 & 24 & $91,6 \%$ & $\begin{array}{c}\text { Sangat } \\
\text { baik }\end{array}$ \\
\hline
\end{tabular}


5325 Pengembangan Multimedia Pembelajaran Interaktif Berbasis Video untuk Meningkatkan Minat Belajar Siswa Sekolah Dasar - Sri Wulan Anggraeni, Yayan Alpian, Depi Prihamdani, Euis Winarsih DOI: https://doi.org/10.31004/basicedu.v5i6.1636

Dari hasil tanggapan guru pada tabel diatas, produk multimedia pembelajaran interaktif berbasis video memperoleh skor rata-rata pada aspek isi/materi sebesar 93,7\% dengan kategori sangat baik, serta perolehan rata-rata aspek media sebesar $91,6 \%$ dengan kategori sangat baik. Maka dapat dinyatakan bahwa produk yang dikembangkan sangat baik dilihat pada segi aspek isi/materi dan aspek media.

\section{Hasil Minat Belajar Siswa}

Uji N-gain digunakan untuk mengetahui seberapa besar peningkatan minat belajar siswa melalui media pembelajaran video interaktif. Adapun hasil perolehan minat belajar siswa disajikan pada tabel berikut ini.

Tabel 8. Hasil Pengukuran Minat Belajar Siswa dengan Uji-Gain

\begin{tabular}{lc}
\hline \multicolumn{1}{c}{ Perlakuan } & Skor \\
\hline Rata-rata nilai Pretest & 26,85 \\
\hline Rata-rata nilai Postest & 38,19 \\
\hline Nilai Maksimal & 44 \\
\hline$N$-Gain & 0,65 \\
\hline \multicolumn{1}{c}{ Kesimpulan } & Sedang \\
\hline
\end{tabular}

Berdasarkan pada tabel di atas menunjukan bahwa perolehan hasil minat belajar siswa kelas $\mathrm{V}$ sekolah dasar sebelum dan setelah menggunakan produk multimedia pembelajaran interaktif berbasis video menunjukan nilai rata-rata pretest sebesar 26,85 dan nilai rata-rata postest sebesar 38,19. Berdasarkan temuan uji $\mathrm{N}$-gain, peningkatan minat belajar siswa memiliki nilai gain 0,65 yang tergolong sedang berdasarkan kriteria gain factor.

Aspek minat belajar diantaranya, aspek perasaan siswa dan perhatian siswa. Jika perolehan dari pengukuran minat belajar siswa diukur per-indikator, maka hasil yang diperoleh sebagai berikut:

Tabel 9. Pengukuran Minat Belajar Per-Aspek

\begin{tabular}{cccccc}
\hline \multicolumn{1}{c}{ Aspek } & Pretest & Postest & Nilai Maks & N-Gain & Kategori \\
\hline Perasaan Senang & 13,92 & 20,22 & 24 & 0,61 & Sedang \\
\hline Perhatian Siswa & 12,92 & 17,85 & 20 & 0,69 & Sedang \\
\hline
\end{tabular}

Berdasarkan tabel tersebut, maka jika dijabarkan per-indikator, setiap indikator minat belajar mengalami peningkatan hasil pada kategori yang berbeda. Setelah menggunakan multimedia interaktif berbasis video siswa mengalami peningkatan perasaan senang terhadap pembelajaran tergolong sedang dengan perolehan hasil $\mathrm{N}$-gain sebesar 0,61 . Sedangkan pada indikator perhatian siswa, siswa mengalami peningkatan minat belajar pada kategori sedang dengan perolehan $\mathrm{N}$-gain sebesar 0,69.

Pemerolehan hasil pengukuran minat belajar di atas diperoleh N-gain sebesar 0,69 membuktikan bahwa dengan penggunaan multimedia interaktif berbasis video dapat meningkatkan minat belajar siswa. Siswa menjadi lebih semangat belajar, focus terhadap materi. Hal ini sejalan dengan Hamalik (Kustandi \& Darmawan, 2020) menyatakan bahwa penggunaan media dalam pembelajaran merupakan proses belajar dan mengajar yang dapat memicu keinginan dan minat siswa, memberikan motivasi dan merangsang proses belajar, serta memberikan dampak psikologis bagi siswa. Penggunaan multimedia interaktif berbasis video juga berdampak pada pemahaman siswa terhadap materi. Dengan adanya penjelasan melalui animasi yang menarik dapat memudahkan siswa lebih paham terhadap materi. Senada dengan Kustandi, Sujipto (2011) mengungkapkan bahwa media pembelajaran adalah alat untuk meningkatkan kegiatan belajar mengajar dengan memperjelas makna pesan yang disampaikan, sehingga memungkinkan tercapainya tujuan pembelajaran dengan lebih baik dan tepat (Kustandi \& Sutjipto, 2011; Luzón \& Letón, 2015; Paseleng \& Arfiyani, 2015). 
5326 Pengembangan Multimedia Pembelajaran Interaktif Berbasis Video untuk Meningkatkan Minat Belajar Siswa Sekolah Dasar - Sri Wulan Anggraeni, Yayan Alpian, Depi Prihamdani, Euis Winarsih DOI: https://doi.org/10.31004/basicedu.v5i6.1636

Pada penelitian ini, media yang dikembangkan adalah multimedia interaktif berbasis video karena media tersebut dapat menyampaikan materi pelajaran dengan menarik yang sesuai dengan karakteristik siswa sekolah dasar. Penggunaan beberapa media untuk menyajikan informasi disebut sebagai multimedia. Teks, grafik, animasi, foto, video, dan suara semua dapat dimasukkan dalam kombinasi ini (Ivers \& Barron, 2002). Media pembelajaran berbasis multimedia interaktif dapat berpengaruh positif terhadap pembentukan minat belajar siswa (Paseleng \& Arfiyani, 2015). Apalagi pengemasan program penggunaan dan metode medianya menggunakan karakter kartun yang sangat digemari oleh anak-anak (Nusir et al., 2013). Penggunaan efek animasi dalam multimedia interaktif dapat membantu siswa belajar lebih efektif dengan memfasilitasi proses kognitif (Luzón \& Letón, 2015). Oleh karena itu, multimedia interaktif berbasis video pada penelitian ini disajikan dengan memberikan konten yang dapat menarik minat siswa dalam belajar. Pemilihan tampilan layar, teks, gambar, animasi maupun backsound dikemas dengan semenarik mungkin berdasarkan karakteristik usia siswa sekolah dasar sehingga siswa dapat menikmati proses pembelajarancara penyajiannya dengan menggunakan animasi sehingga dapat menarik perhatian siswa dalam melaksanakan kegiatan belajar.

\section{KESIMPULAN}

Produk yang dikembangkan dalam penelitian ini adalah multimedia interaktif berbasis video untuk meningkatkan minat belajar siswa. Hasil penelitian menunjukkan bahwa minat belajar siswa yang diajarkan melalui pembelajaran berbasis multimedia interaktif lebih tinggi dibandingkan sebelum menggunakan multimedia, menurut temuan tersebut. Rata-rata skor pretes 26,85 , dan rata-rata skor postes 38,19 , dengan skor tertinggi 44, menunjukkan adanya peningkatan minat belajar siswa sebelum dan sesudah perlakuan dengan produk multimedia pembelajaran interaktif berbasis video. Berdasarkan hasil uji N-gain, peningkatan minat belajar siswa memperoleh nilai gain 0,65 yang tergolong pada kategori sedang. Hal ini menunjukkan bahwa penggunaan multimedia interaktif dapat membantu siswa belajar lebih berhasil.

\section{DAFTAR PUSTAKA}

Arsyad, A. (2016). Media Pembelajaran. Jakarta: Rajawali Pers.

Awalia, L. M., Ika Ari Pratiwi, \& Kironoratri, L. (2021). Analisis Penggunaan Aplikasi Pembelajaran Daring Terhadap Minat Belajar Siswa Di Desa Karangmalang. Basicedu, 5(5), 3940-3949. Https://Doi.Org/Https://Doi.Org/10.31004/Basicedu.V5i5.1354

Baharun, H. (2016). Pengembangan Media Pembelajaran Pai Berbasis Lingkungan Melalui Model Assure. Cendekia: Jurnal Kependidikan Dan Kemasyarakatan, 14(2), 231-246. Https://Doi.Org/Https://Doi.Org/10.21154/Cendekia.V14i2.610

Bintas, J., \& Gelibolu, M. F. (2010). The Evaluation Of Introduction Level Computer-Assisted Symbolic Logic Materials Based On Realistic Mathematics Education And Guided Discovery Learning Approach. International Journal Of Instructional Technology And Distance Learning, 7(2), 61-71. Retrieved From Https://Www.Itdl.Org/Journal/Feb_10/Article05.Htm

Darmadi. (2017). Pengembangan Model Dan Metode Pembelajaran Dalam Dinamika Belajar Siswa. Yogyakarta: Deepublish.

Fauziah, A., Rosnaningsih, A., \& Azhar, S. (2017). Hubungan Antara Motivasi Belajar Dengan Minat Belajar Siswa Kelas Iv Sdn Poris Gaga 05 Kota Tangerang. Jpsd (Jurnal Pendidikan Sekolah Dasar), 4(2), 4853. Https://Doi.Org/Http://Dx.Doi.Org/10.12928/Jpsd.V4i2.9594

Friantini, R. N., \& Winata, R. (2019). Analisis Minat Belajar Pada Pembelajaran Matematika. Jpmi (Jurnal Pendidikan Matematika Indonesia), 4(1), 6. Https://Doi.Org/10.26737/Jpmi.V4i1.870

Ivers, K. S., \& Barron, A. E. (2002). Multimedia Projects In Education: Designing, Producing, And 
5327 Pengembangan Multimedia Pembelajaran Interaktif Berbasis Video untuk Meningkatkan Minat Belajar Siswa Sekolah Dasar - Sri Wulan Anggraeni, Yayan Alpian, Depi Prihamdani, Euis Winarsih DOI: https://doi.org/10.31004/basicedu.v5i6.1636

Assessing. Westport, Ct: A Division Of Greenwood Publishing Group, Inc.

Komariyah, S., Afifah, D. S. N., \& Resbiantoro, G. (2018). Analisis Pemahaman Konsep Dalam Memecahkan Masalah Matematika Ditinjau Dari Minat Belajar Siswa. Sosiohumaniora, 4(1), 1-8. Https://Doi.Org/Http://Dx.Doi.Org/10.30738/Sosio.V4i1.1477

Kustandi, C., \& Darmawan, D. (2020). Pengembangan Media Pembelajaran Konsep Dan Aplikasi Pengembangan Media Pembelajaran Bagi Pendidik Di Sekolah Dan Masyarakat. Jakarta: Prenada Media Group.

Kustandi, C., \& Sutjipto, B. (2011). Media Pembelajaran: Manual Dan Digital. Bogor: Bogor Ghalia Indonesia.

Luzón, J. M., \& Letón, E. (2015). Use Of Animated Text To Improve The Learning Of Basic Mathematics. Computers \& Education, 88, 119-128. Https://Doi.Org/10.1016/J.Compedu.2015.04.016

Niswa, A. (2012). Pengembangan Bahan Ajar Mendengarkan Berbasis Video Interaktif Bermedia Flash Kelas Viid Smp Negeri 1 Kedamean. Jurnal Bahasa Dan Sastra Indonesia, 1(1), 1-16.

Nusir, S., Alsmadi, I., Al-Kabi, M., \& Sharadgah, F. (2013). Studying The Impact Of Using Multimedia Interactive Programs On Children's Ability To Learn Basic Math Skills. E-Learning And Digital Media, 10(3), 305-319. Https://Doi.Org/10.2304/Elea.2013.10.3.305

Paseleng, M. C., \& Arfiyani, R. (2015). Pengimplementasian Media Pembelajaran Berbasis Multimedia Interaktif Pada Mata Pelajaran Matematika Di Sekolah Dasar. Scholaria: Jurnal Pendidikan Dan Kebudayaan, 5(2), 131. Https://Doi.Org/10.24246/J.Scholaria.2015.V5.I2.P131-149

Putrayasa, I. M., Syahruddin, H., \& Margunayasa, I. G. (2014). Pengaruh Model Pembelajaran Discovery Learning Dan Minat Belajar Terhadap Hasil Belajar Ipa Siswa. Jurnal Mimbar Pgsd Universitas Pendidikan Ganesha, 2(1). Https://Doi.Org/Http://Dx.Doi.Org/10.23887/Jjpgsd.V2i1.3087

Saifudin, M., Susilaningsih, S., \& Wedi, A. (2020). Pengembangan Multimedia Interaktif Materi Sumber Energi Untuk Memudahkan Belajar Siswa Sd. Jktp: Jurnal Kajian Teknologi Pendidikan, 3(1), 68-77. Https://Doi.Org/10.17977/Um038v3i12019p068

Trianto. (2009). Mendesain Model Pembelajaran Inovatif Progresif: Konsep, Landasan, Dan Implementasinya Pada Kurikulum Tingkat Satuan Pendidikan (Ktsp). Jakarta: Kencana.

Wulandari, R. M., Widyaningrum, L., \& Arini, L. D. D. (2021). Pengaruh Inovasi Cerdas Pada Sistem Muskuloskeletal Melalui Media Pembelajaraninteraktif Di Sekolah Dasa. Jurnal Basicedu, 5(5), 3034 3042. Https://Doi.Org/Https://Doi.Org/10.31004/Basicedu.V5i5.1205 